\title{
The World of Women Public Relations Practitioners in Qatar
}

\author{
Mohamed Kirat, Ph.D. \\ Professor, Department of Mass Communication \\ College of Arts and Sciences \\ Qatar University, Doha, Qatar
}

\begin{abstract}
This study presents a portrait of the female PR practitioner in Qatar drawn from a questionnaire administered to 156 practitioners from both government and private sector. Public relations in Qatar has emerged over the last three decades to become a well-established profession with international public relations firms, PR programs and majors in the department of Mass Communication at Qatar University and Northwestern University. The study investigates the backgrounds, professional orientations and working conditions of the female PR practitioners in Qatar, as well as their age, nationalities, professional values, $P R$ and public opinion, PR functions and roles, $P R$ ethics, concepts, working conditions and job satisfaction, $P R$ and information technology. The study suggests that $94 \%$ of the female PR practitioners are nationals, $92 \%$ of them are married and hold a bachelor degree with one third of them majoring in public relations. In terms of professional values, the majority of the practitioners did not mention the strategic roles of $P R$ such as research, strategic planning, managerial roles and decision-making support. Findings show that more than two thirds of the surveyed practitioners objected to the use of unethical methods to reach the goals of the organization. Practitioners in this study have also a strong belief that public relations play a major role in building a good corporate image for the organization and good relations with its publics. Women PR practitioners admit that public relations in Qatar focus on publicity and media liaising (Grunig Press a gentry and general Information models) and do not use research and lacks qualified professionals.
\end{abstract}

Keywords: Women PR practitioners, professional orientations, working conditions, job satisfaction, social media use.

\section{Introduction}

A fast growing and a rapidly developing country, the state of Qatar is a young emerging nation going through a process of drastic development and social change. In 1995, the father emir Hamad bin Khalifa Al Thani started new political and media reforms, unprecedented economic investment, and a growing Qatari regional leadership role, through new regional and international policies and the establishment in 1996 of the pan-Arab satellite news network Al-Jazeera as well as Qatar's mediation of some regional conflicts. By 2007, Qatar had attained the highest per capita income in the world. Qatar did not experience domestic unrest or violence like that seen in other Near Eastern and North African countries in 2010-11, due in part to its immense wealth. In mid-2013, the father emir peacefully transferred power to his son Tamim. The new emir enjoys great popularity and loyalty of his people, having prioritized improving the domestic welfare of Qataris, including establishing advanced healthcare and education systems and expanding the country's infrastructure in anticipation of Doha's hosting of the 2022 soccer World Cup.(https://www.cia.gov/library/publications/the-world-factbook/geos/qa.html).

The public relations industry in the country is relatively young and new like the country itself, which was established on December18of 1971. The PR industry is in its formation stage with only about four decades of age. On its website, Qatar Ministry of interior posted the following: The need of human being for communication with others and exchanging thoughts is old as humanity's existence. Along with the progress of humanity, the importance of public relations arose as a concept to achieve human understanding, communicate with others, transferring experience, expertise and information, which necessitate the importance of sound planning to reach a mutual understanding. From the beginning of seventies, the Ministry of Interior has given necessary importance for public relations considering it as a channel of contact and communication with individuals of society. In 1979, the then H.E. Minister of Interior issued a ministerial decree to form an independent department named "Public Relations Department". https://portal.moi.gov.qa/wps/portal/MOIInternet/departmentcommittees/publicrelations. 
For its small size in area and population of 2.3 million inhabitants, Qatar has a good media infrastructure. The country has five dailies in Arabic, three in English, more than two hundred magazines and periodicals, five satellite television channels, and six radio stations, in addition to Aljazeera network with an audience of over forty million viewers. In terms of advertising expenditure, Qatar ranks among the top 10 countries in the Arab World thanks to its flourishing economy and to the strong purchasing power of its citizens. According to Internet World Statistics, Internet penetration in the country is among the highest in the world with $97.4 \%$. Out of a population of 2,258,283, a score of 2,200,000 people have Internet. (http://www.internetworldstats.com/me/qa.htm).

The rationale behind this study is to find out whom the women PR practitioners in Qatar are, where they come from, how they perceive of their job and role in society. The integration of women in the QatariPR industry is very successful thanks to a good number of female graduates from Qatar University and other higher educational institutions in neighboring countries and thanks also to the women emancipation in the workforce in the country.

\section{The Problem}

As a fast emerging growing country, Qatar cannot aspire to a good development process without the participation of more than half of the population. In addition the majority of students enrolled in universities and various high education institutions are female - over two thirds. In the department of Mass Communication at Qatar University $60 \%$ of students enrolled chose as their major strategic communication. To what extent women are working in public relations. Good involvement of women in the public relations industry might be good indicator of female participation in the development process. Both the quantity and the quality of such participation might help determine largely what kind of input do women have in society.

\section{Purpose of the study}

This study addresses the issue of educational background, working conditions and professional orientations of women public relations practitioners in Qatar. This study also assesses what kind of roles and activities are PR departments playing in the development process of the country. How women practitioners in Qatar conceive of PR; what about their job satisfaction, working conditions, relations with media and their organization's publics. What about the use of social media and research to perform their tasks, and engage in the development process of the country in various aspects of life?

\section{Women in Qatar}

Soon after the creation of the state of Qatarin December18, 1971, the leaders of the country took the issue of women emancipation seriously. The decision makers in Qatar were convinced that the country could not aspire to a healthy and sustainable development without the participation and integration of women in all aspects of life. Women in Qatar represent more than half of the population. During the sixty-first session of the Commission on the Status of Women, Najat Daham Al Abdullah, who is the director of family affairs at the Ministry of Administrative Development, Labor, and Social Affairs stated:.

In light of gaining high rankings in recent years in the Human Development Index, Qatar remained committed to ensure that the benefit of that growth goes to women and men equally. The statement noted that Qatar National Vision 2030 prioritized the empowerment of women through her right to work and enhancing social protection for women. Qatar also remains committed to all the international and regional agreements it signed on the rights of women led by The UN's Convention on the Elimination of All Forms of Discrimination against Women, the statement added. Qatar's statement then discussed the legislation in Qatar and highlighted that it prevents discrimination against women when it comes to employment, whether in the public or private sector. It also provides women with equal opportunities with men in the assumption of leadership positions. (https://www. thepeninsulaqatar.com/article/18/03/2017/Qatar-stresses-commitment-to-women-s-empowerment-in-all-fields.

The last 10 years have seen many positive developments in the integration of Qatari women in the workplace. Qatar University's latest graduating class comprised about 75\% women. (https://www.forbesmiddleeast. com/en/qatari-women-in-the-workplace/). Her Highness Sheikha Jawaher bint Hamad bin Suhaim Al Thani graced QU graduation ceremony of 1708 female students of Class of 2016 on June 2. A recent study has found that 51 percent of women in Qatar are in the workforce, making it the highest rate of female employment across the Gulf cooperation countries (GCC). (https://www.alaraby.co.uk/english/society/2016/3/19/qatar-celebratesgulfs-highest-rates-of-women-in-work). Women dominate Seventy percent of the Technical professions such as physicians, pharmacists, and schoolteachers. Qatari women have participated in many fields and achieved educational excellence in most specializations. Qatari women occupy many important positions in Qatar. 
Notably, women in Qatar have contributed massively in the fields of education, health, cultural institutions, arts, law, public relations, tourism, hospitality, banks and other sectors. Politically, women in Qatar achieved suffrage in 1997, long before its neighbors Bahrain, Oman, Kuwait, the UAE and Saudi Arabia followed suit.

In 1998, the role of women in the field of investment and financial affairs became more prominent through the establishment of an investment company for women. The company is a joint venture between a group of Qatari women and Qatar International Bank, and managed by Sheikha Hanadi Bint Nasser Al Thani. In 2000, The Qatari Business Women Forum was established within the Qatar Chamber of Commerce, it is a body that aims to create a favorable environment for women to contribute effectively in the development of projects and enhance their role in economic decision-making for the betterment of the Qatari economy and its society.

In modern day Qatar, women are competing equally with men in the workplace in terms of quality of work and tenacity. They are supported largely by seeing members of their sex in important and outspoken positions within government, who are demanding and achieving equal rights and status in what has traditionally been a maledominated region and society. The Supreme Council for Family Affairs, established in 1998, suggests policies, plans and programs necessary for developing Qatari women culturally, economically and politically. It also works on encouraging women to participate in public life and seize the available opportunities in education and employment. Other high education institutions in the country are forming thousands of female graduates in various fields of technology, sciences and humanities each year. In the field of public relations, figures show that $67 \%$ of the work forces are female. This is a good indicator of the Qatari women emancipation in General and in PR industry in particular.

\section{Research Questions}

Q1: What are the socio-demographic and educational backgrounds of women PR practitioners in Qatar?

Q2: What are their professional values and ethics?

Q3: What are the working conditions of the PR practitioner's in Qatar?

Q4: How do women PR practitioners in Qatar perceive of the PR profession?

Q5: How do women PR practitioners in Qatar perceive of the roles of PR in society and its impact on public opinion?

\section{Methodology}

This study used the survey method. An 80-item questionnaire was administered to women PR practitioners working in Qatar. The research intended to cover the whole women PR work force in Qatar, which is estimated at 600, working for in house PR departments. The convenience sample was used. The researcher was able to collect 156 questionnaires from 48 organizations representing almost all Qatari government departments as well as semi private and private companies.

\section{Questionnaire construction, administration and data collection}

The construction of the survey was based on the issues that the research looks at. No PR practitioners profile studies were found; however, the researcher looked at journalists profile studies done in more than 34 countries around the world (Tunstall, 1997; Weaver and Wilhoit 1986, 1996; Weaver and Willnat 2012, Kirat, 1993, 1998, 2012, 2016).As for the administration of the questionnaire, two research assistants helped in administering the questionnaires. They distributed the questionnaires in all the PR departments in the country and went back to collect them. Jasem Fakhro, former chair of the IPRA Gulf chapter, and Maryam Alhamadi a Public Relations and Communication advisor estimated the number of PR practitioners in Qatar at 1000 of whom 600 are female. This study covered 156 female practitioners which represent $25 \%$ of the total female PR practitioners in Qatar, which I believe is representative. As for the organizations represented in the study, the results show the following: media organizations $(16 \%)$, higher education (14\%), oil and gas companies (8\%), government services department $(8 \%)$ tourism $(8 \%)$, sports organizations $(6 \%)$, hospitals and health organizations $(6 \%)$, cultural institutions (4\%), religious and welfare organizations (4\%).

The questionnaire covered the following topics: Professional orientations of practitioners, perception pf PR, PR ethics, working conditions, job satisfaction, PR performance evaluation, strengths and weaknesses of the practice of PR in Qatar. The questionnaire also covered the use of new media by PR practitioners, functions and role of PR, internal communication, and external communication, media used by PR, dealing with crises, PR research, and suggestions to improve the profession of public relations in Qatar. The questionnaires were distributed to women PR practitioners and PR managers and heads of PR departments. 


\section{Findings}

The findings from this survey offer a detailed and current profile of the demographics, education, job satisfaction, working conditions, roles, news values, ethics, professional orientations, and perceived impact on public opinion of this group of women PR practitioners in Qatar.

\section{Demographics}

More than three fourths (78.2\%) of the surveyed PR practitioners in this study fall in the 20-30 age bracket with a median of 28 years old. Only $3.9 \%$ of the surveyed practitioners were aged between 45 and 50 years old and $1.3 \%$ aged between 50-55 years old. PR practitioners in Qatar have 8.12 years of experience in the field and work an average of 35 hours per week. Over three-quarters of the PR, practitioners surveyed are married (76.6\%), while $20.40 \%$ are single and have never married. The majority (92\%) of the surveyed practitioners are Qataris. This is a very positive indicator given the fact that expatriate employees dominate most of the fields in the country. If we take the media sector as an example, more than $90 \%$ of the media employees are expatriates; Qataris do not represent more than $10 \%$ of the workforce in the media industry.

\section{Education and Training}

Over two thirds of the surveyed PR practitioners in this study hold a bachelor's degree (71\%) and $2.5 \%$ hold advanced degrees (table 1.1). Over three fourths holding a bachelor's degree have a major in journalism and mass communication (76\%), while other majors include business (5.2\%), English language (4\%), information technology $(3.5 \%)$, natural sciences $(2.8 \%)$, and humanities $(2.1 \%)$. Findings of the study show that there was only one interviewee majoring in public relations. This is a striking finding, given the fact that each year, tens of female students graduate in public relations from Qatar University and Northwestern University in Qatar. Concerning continuing education, $90 \%$ of the surveyed PR practitioners expressed interest in additional training in public relations. The majority of the respondents would like to have training in PR writing (70\%), followed by an interest in learning more about the use of social media in PR (50\%), event management (40\%), PR research techniques (20\%), and PR campaigns (15\%). The findings suggest that age and experience are the key factors in determining whether the PR practitioner is interested in having more training and continuous education. More than two thirds of the surveyed PR practitioners had public relations training before entering the profession $(70 \%)$.

Table 1.1 PR practitioners' level of education (in $\%, N=156$ )

\begin{tabular}{lc}
\hline High school & 32.1 \\
Bachelor & 65.4 \\
Master & 1.9 \\
PhD & .6 \\
Total & 100.0 \\
\hline
\end{tabular}

\section{Job satisfaction and working Conditions}

Eighty percent of the PR practitioners were fairly satisfied and very satisfied with their jobs, while $14.4 \%$ said they were somewhat dissatisfied and only $2.4 \%$ said they were very dissatisfied (table 2.1). Eighty-four percent said their working conditions were either very good or good.

Table 2.1 Job satisfaction (in \%, $N=156$ )

\begin{tabular}{lc}
\hline Very dissatisfied & 3.7 \\
Somewhat dissatisfied & 15.5 \\
Fairly satisfied & 50.0 \\
Very satisfied & 30.0 \\
Don't know & .8 \\
Total & 100.0 \\
\hline
\end{tabular}

Concerning their working conditions, (table 2.2) three fourths of the surveyed PR practitioners (88.4\%) said they are either very good or good. This is a positive indicator for a good work environment and an encouraging engagement from public relations practitioners. 
Table 2.2 Working conditions (in $\%, N=156$ )

\begin{tabular}{lc}
\hline Very good & 47.6 \\
Good & 40.8 \\
Some problems & 9.4 \\
Very bad & 2.1 \\
Total & 100.0 \\
\hline
\end{tabular}

Regarding PR practitioners' attitudes toward various aspects of their jobs, Table 2.3 shows that most PR practitioners surveyed are satisfied or very satisfied with their peer relationships $(92.2 \%)$, job stability $(86.4 \%)$, use of talents and creativity (82.4\%), extent of freedom (73.6\%), and relationships with sources $(69.6 \%)$. The attitudes of these PR practitioners indicate that they are generally positive and happy about the job atmosphere and their working conditions, which is a good indicator of a healthy public relations practice in Qatar.

Table 2.3 PR practitioners' Attitudes towards Job-related Issues (in \%, $N=156$ )

\begin{tabular}{|c|c|c|c|c|c|c|}
\hline & $\begin{array}{c}\text { Very } \\
\text { satisfied }\end{array}$ & Satisfied & Dissatisfied & $\begin{array}{c}\text { Strongly } \\
\text { dissatisfied }\end{array}$ & $\begin{array}{c}\text { No } \\
\text { opinion }\end{array}$ & Total \\
\hline Peer relationships & 37.6 & 54.4 & 4.8 & 1.6 & 5.6 & 100.0 \\
\hline Relationship with media & 18.4 & 51.2 & 13.6 & 2.4 & 14.4 & 100.0 \\
\hline $\begin{array}{l}\text { Use of talents \& } \\
\text { creativity }\end{array}$ & 27.2 & 55.2 & 8.8 & 3.2 & 5.6 & 100.0 \\
\hline Attitude toward job & 26.4 & 60.8 & 5.6 & 1.6 & 5.6 & 100.0 \\
\hline Stability in the job & 24.8 & 61.6 & 4.8 & 0.8 & 8.0 & 100.0 \\
\hline Extent of freedom & 17.6 & 56.0 & 9.6 & 7.2 & 9.6 & 100.0 \\
\hline
\end{tabular}

Table 2.4 shows practitioners' opinions about criticism of the practice of public relations in Qatar. Over two thirds of the practitioners strongly agree or agree with the following statements: "Concentrates on publicity and media coverage" (70.4\%), "Focus on routine activities" (67.8\%),"Absence of studies and research" (67.8\%) and "Lack of planning" (66.8\%).More than half of the interviewees strongly or agree with the following: "Sides with the organization or the client' (60.1\%), and "Hides organization's weaknesses and focus on its strength" (54.4\%). On the other hand, more than half of the practitioners strongly disagree and disagree with following: "Lack of qualified practitioners" 53.4\%), "Lack of interest in public complaints and suggestions" (53.2\%) and "Do not respect professional ethics" (52.8\%).

Table 2.4 PR practitioners' Opinions about Criticism of Qatar PR (in \%, $N=156$ )

\begin{tabular}{|c|c|c|c|c|c|c|}
\hline & $\begin{array}{c}\text { Strongly } \\
\text { Agree }\end{array}$ & Agree & No Opinion & Disagree & $\begin{array}{l}\text { Strongly } \\
\text { Disagree }\end{array}$ & $\begin{array}{c}\text { Total } \\
\%\end{array}$ \\
\hline $\begin{array}{l}\text { Concentrates on publicity and } \\
\text { media coverage }\end{array}$ & 38.6 & 31.8 & 14.2 & 13.7 & 1.7 & 100.0 \\
\hline $\begin{array}{l}\text { Sides with the organization or } \\
\text { the client }\end{array}$ & 30.9 & 29.2 & 19.7 & 17.6 & 2.6 & 100.0 \\
\hline Focus on routine activities & 41.2 & 26.6 & 15.9 & 13.7 & 2.6 & 100.0 \\
\hline Absence of studies and research & 38.6 & 29.2 & 12.9 & 15.9 & 3.4 & 100.0 \\
\hline $\begin{array}{l}\text { Lack of interest in public } \\
\text { complaints and suggestions }\end{array}$ & 12.4 & 18.0 & 16.3 & 41.2 & 12.0 & 100.0 \\
\hline $\begin{array}{l}\text { Hides organization's weaknesses } \\
\text { and focus on its strength }\end{array}$ & 26.4 & 28.0 & 12 & 24 & 9.6 & 100.0 \\
\hline One Way Communication & 14.6 & 19.7 & 24.5 & 35.2 & 6.0 & 100 \\
\hline Lack of planning & 30.0 & 36.8 & 7.2 & 18.0 & 8.0 & 100.0 \\
\hline $\begin{array}{l}\text { Lack of interest in the internal } \\
\text { audience }\end{array}$ & 18.0 & 15.5 & 18.5 & 38.2 & 9.9 & 100.0 \\
\hline $\begin{array}{l}\text { Does not respect professional } \\
\text { ethics }\end{array}$ & 9.9 & 12.0 & 25.3 & 38.6 & 14.2 & 100.0 \\
\hline Lack of qualified practitioners & 16.8 & 19.2 & 10.6 & 35.2 & 18.2 & 100.0 \\
\hline $\begin{array}{l}\text { Not enough PR employees } \\
\text { (understaffed) }\end{array}$ & 31.2 & 16.8 & 13.6 & 25.6 & 12.8 & 100.0 \\
\hline $\begin{array}{l}\text { No interest in developing } \\
\text { employees skills and } \\
\text { competencies }\end{array}$ & 25.6 & 17.6 & 12.8 & 27.2 & 16.8 & 100.0 \\
\hline
\end{tabular}




\section{Public Relations Roles}

The data in Table 3.1 suggest that the women PR practitioners' definitions and philosophical views of public relations roles revolve around the classical functions of PR namely press agentry, public information, and publicity. The majority of women practitioners in Qatar said that it is extremely important for public relations to: "Provide information about the organization" (78.1\%)," Respond to public complaints" (75.5\%), Provide media organizations with news and information about the organization $(72.1 \%)$ Investigate complaints and public statements $(69.1 \%)$, Focus on information that matters to the largest audience $(68.1 \%)$, carry out research and studies (67.5\%). Over half of the respondents answered that it is extremely important for public relations to play the following roles: "Stay away from misinformation and exaggerate the positives of the organization" (60.5\%), "Carry out polls to assess organization's publics opinion" (60\%), "Provide necessary information to the public" $(55.2 \%)$. Respondents agreed with the following: "Provide the necessary information for the internal public" (52.8\%), and "Responding to rumors and biased propaganda against the organization" (52.2\%).

Table 3.1 Importance of Public Relations Roles (in \%, $N=\mathbf{1 5 6}$ )

\begin{tabular}{|c|c|c|c|c|c|c|}
\hline & $\begin{array}{l}\text { Extremely } \\
\text { important }\end{array}$ & $\begin{array}{c}\text { Quite } \\
\text { important }\end{array}$ & $\begin{array}{l}\text { Somewhat } \\
\text { important }\end{array}$ & $\begin{array}{l}\text { Not really } \\
\text { important }\end{array}$ & No opinion & $\begin{array}{c}\text { Total } \\
\%\end{array}$ \\
\hline $\begin{array}{l}\text { Provide information about the } \\
\text { organization }\end{array}$ & 78.1 & 13.1 & 6.4 & 0.4 & 0 & 100.0 \\
\hline Respond to public complaints & 75.5 & 14.2 & 7.7 & 1.7 & 0.9 & 100.0 \\
\hline $\begin{array}{l}\text { Provide media organizations with news } \\
\text { and information about the organization }\end{array}$ & 72.1 & 18.0 & 6.9 & 2.1 & 0.9 & 100.0 \\
\hline $\begin{array}{l}\text { Investigate complaints and public } \\
\text { statements }\end{array}$ & 69.1 & 18.9 & 9.4 & 0.9 & 1.7 & 100.0 \\
\hline $\begin{array}{l}\text { Stay away from misinformation and } \\
\text { exaggerate the positives of the } \\
\text { organization }\end{array}$ & 60.5 & 19.3 & 15 & 3.4 & 1.7 & 100.0 \\
\hline $\begin{array}{l}\text { Focus on information that matters to the } \\
\text { largest audience }\end{array}$ & 68.1 & 21.3 & 8.1 & 0.6 & 1.9 & 100.0 \\
\hline Carry out Research and studies & 67.5 & 15.6 & 4.4 & 8.1 & 4.4 & 100.0 \\
\hline $\begin{array}{l}\text { Carry out polls to assess organization's } \\
\text { publics opinion }\end{array}$ & 60.0 & 22.4 & 11.2 & 1.6 & 4.8 & 100.0 \\
\hline $\begin{array}{l}\text { Provide the necessary information for } \\
\text { the internal public }\end{array}$ & 52.8 & 26.4 & 12.8 & 1.6 & 6.4 & 100.0 \\
\hline $\begin{array}{l}\text { Evaluate public relations activities and } \\
\text { programs }\end{array}$ & 46.4 & 24.8 & 14.4 & 2.4 & 12.0 & 100.0 \\
\hline $\begin{array}{l}\text { Responding to rumors and propaganda } \\
\text { against the organization }\end{array}$ & 52.2 & 21.6 & 12.0 & 2.4 & 8.8 & 100.0 \\
\hline $\begin{array}{l}\text { Organizing social and sports activities } \\
\text { for the Organization's employees }\end{array}$ & 47.2 & 24.0 & 16.8 & 5.6 & 6.4 & 100.0 \\
\hline $\begin{array}{l}\text { Provide necessary information to the } \\
\text { public }\end{array}$ & 55.2 & 17.6 & 15.2 & 4.0 & 8.0 & 100.0 \\
\hline $\begin{array}{l}\text { Follow-up of data and news published } \\
\text { by the media and social networks on the } \\
\text { organization }\end{array}$ & 27.2 & 26.4 & 17.6 & 16.0 & 12.8 & 100.0 \\
\hline $\begin{array}{l}\text { To balance the interests of the } \\
\text { Organization and the interests of the } \\
\text { public and to serve both }\end{array}$ & 33.6 & 32.0 & 30.4 & 3.2 & 0.8 & 100.0 \\
\hline Conduct media campaigns & 36.0 & 25.6 & 16.8 & 13.6 & 8.0 & 100.0 \\
\hline Planning public relations programs & 18.4 & 15.2 & 13.6 & 32.8 & 20.0 & 100.0 \\
\hline Issuing Organization's publications & 13.6 & 11.2 & 18.4 & 39.2 & 17.6 & 100.0 \\
\hline Events management & 40.1 & 10.4 & 20.2 & 20.4 & 8.9 & 100.0 \\
\hline $\begin{array}{l}\text { Provide organization's website with } \\
\text { data and information }\end{array}$ & 36.2 & 15.6 & 25.2 & 21.6 & 1.4 & 100.0 \\
\hline
\end{tabular}

\section{Role of PR in building corporate image}

Women PR practitioners in Qatar believe that PR has a strong impact on building the company's image. In a scale of 0 to 10 where zero means no impact and 10 means strong impact, $42 \%$ of the respondents rated the impact 9 out of $10 ; 23 \%$ said the impact is 8 out of 10 . Overall, the average was 8.5 out of 10 which a relatively high impact is.

\section{Impact of PR on public opinion}

Women PR practitioners in this study believe strongly that Public relations is very influential in shaping and forming public opinion. Asked to rate PR's influence on a 10-point scale (with 10 indicating great influence, and zero no influence at all), PR practitioners scored a mean of 8.5 on the influence of the media on public opinion. 
Results of the study showed a mean of 8.0 on how much public relations influence there should be on public opinion, and a mean of 7.8 on public relations influence on government.

\section{Conception and Definition of Public Relations}

Women PR practitioners in our survey were asked about their conception and definition of public relations. Here are some of the answers: "A process of relationships between the organization and its publics", "Communicate the corporate image to the public", "Managing communication and understanding between the organization, the publics, the media and various stakeholders". "Liaising with media to assure a good media coverage of the organization", "Provide all the necessary information about the organization to the media and the publics". We conclude from these definitions the focus on publicity and media coverage and the technician role of PR at the expense of research, counseling and managerial role. Asked if their conception of public relations has changed since they joined the profession, $40 \%$ said it changed somewhat, and 30\% said it changed great deal.

\section{Ethics}

Since the early days of public relations, the problem of ethics has been posed critically in the circles of the profession and the media industry. Media professionals as well as those many who are concerned with ethics have raised the problem of credibility, truth, trust and morals of those behind the work and crafts of public relations. Many voices have been raised against the vicious and malicious motives of the majority of the public relations activities and programs.

Women PR practitioners in our survey were asked how influential various factors were on their perceptions of public relations ethics. (Table4.1).Respondents found day-by-day learning extremely influential or quite influential (84.8\%), followed by a senior PR practitioner $(80.8 \%)$; a PR manager $(76.8 \%$ ); family upbringing (72.8\%), religious education $(69.6 \%)$, and PR teachers (69.6). These findings indicate that a mixture of religious background and professional socialization has the greatest influence on the ethical attitudes and practices of women PR practitioners in Qatar.

Table 4.1 Factors Influencing Public Relations Ethics (in \%, $N=156$ )

\begin{tabular}{lcccccc}
\hline & $\begin{array}{c}\text { Extremely } \\
\text { influential }\end{array}$ & $\begin{array}{c}\text { Quite } \\
\text { influential }\end{array}$ & $\begin{array}{c}\text { Somewhat } \\
\text { influential }\end{array}$ & $\begin{array}{c}\text { Not really } \\
\text { influential }\end{array}$ & $\begin{array}{c}\text { Don'tkno } \\
\mathbf{w}\end{array}$ & $\begin{array}{c}\text { Total } \\
\text { \% }\end{array}$ \\
\hline High school teachers & 24.8 & 12.0 & 16.0 & 42.4 & 4.8 & 100.0 \\
College teachers & 19.2 & 35.2 & 20.0 & 19.2 & 6.4 & 100.0 \\
PR teachers & 36.8 & 32.8 & 11.2 & 12.8 & 6.4 & 100.0 \\
Family upbringing & 51.2 & 21.6 & 16.8 & 8.8 & 1.6 & 100.0 \\
Religious education & 52.0 & 17.6 & 18.4 & 8.8 & 3.2 & 100.0 \\
Day by day learning & 59.2 & 25.6 & 11.2 & 2.4 & 1.6 & 100.0 \\
A senior PR practitioner & 46.4 & 30.4 & 13.6 & 6.4 & 3.2 & 100.0 \\
A senior PR manager & 44.0 & 36.8 & 9.6 & 7.2 & 2.4 & 100.0 \\
\hline
\end{tabular}

Table 4.2 shows PR practitioners' attitudes about controversial reporting practices that might generate ethical problems. Respondents were asked whether they would not approve of the action, or whether it would be justified on occasion. Findings show that in all instances the majority of the surveyed PR practitioners would not approve of the following: "Favours organization's interest over publics' interest" (65.6\%); "Using misleading information and figures" (76.8\%); "Favours personal's interest over publics' interest" (75.2); "Giving false promises" (87.2\%); "Amplifying positive things and hiding negative ones" (84\%). They also objected to "Offering presents to journalists" (64\%); "Hacking competing companies' secrets" (75.2\%); "Using and exploiting journalists" (75.2\%); "Making up events and amplifying them" (84\%); “Accepting gifts from clients" (85.^\%),"Distorts competitors' reputation" (87.6\%); "providing misleading information to satisfy senior management" $(85.2 \%)$; "Providing misleading information to satisfy the public" (82.5\%). Women PR practitioners were against the following:"Uses women to attract customers" (75\%); "Adulation" (81\%);"Misinformation and manipulation" (82\%); "spreads rumors" (90\%) and "manipulating public opinion" $(85.5 \%)$.

These findings reflect the commitment of PR practitioners to a strong ethical stance, yet also their reluctance to engage in activities that may have undesirable consequences. In addition, PR practitioners' Arab-Islamic culture encourages them to avoid controversial and personal issues. However, these findings do not indicate that unethical practices never occur, although when they happen, they may differ from the examples we introduced. 
Table 4.2PR Practitioners' Attitudes towards Ethical Issues (in \%, $N=156$ )

\begin{tabular}{lccccc}
\hline & $\begin{array}{c}\text { Justified } \\
\text { on } \\
\text { occasion }\end{array}$ & $\begin{array}{c}\text { Would } \\
\text { not } \\
\text { approve }\end{array}$ & Not sure & $\begin{array}{c}\text { Don't } \\
\text { know }\end{array}$ & Total \% \\
\hline $\begin{array}{l}\text { Favours organization's interest over } \\
\text { publics' interest }\end{array}$ & 17.6 & 65.6 & 8.0 & 8.8 & 100.0 \\
Using misleading information and figures & 12.8 & 76.8 & 4.8 & 5.6 & 100.0 \\
Favours personal's interest over publics' & 15.2 & 75.2 & 4.0 & 5.6 & 100.0 \\
interest & & & & & \\
Giving false promises & 5.6 & 87.2 & 1.6 & 5.6 & 100.0 \\
Amplifying positive things and hiding & 18.4 & 71.2 & 3.2 & 7.2 & 100.0 \\
negative ones & & & & & \\
Offering presents to journalists & 8.0 & 64.0 & 24.8 & 3.2 & 100.0 \\
Hacking competing companies' secrets & 16.0 & 75.2 & 4.0 & 4.8 & 100.0 \\
Using and exploiting journalists & 18.4 & 75.2 & 4.0 & 2.4 & 100.0 \\
Making up events and amplifying them & 8.8 & 84 & 4.0 & 3.2 & 100.0 \\
Accepting gifts from clients. & 5.6 & 85.6 & 4.0 & 4.8 & 100.0 \\
Distorts competitors' reputation & 4.3 & 87.6 & 5.2 & 3.0 & 100.0 \\
Providing misleading information & 5.0 & 85.2 & 4.9 & 4.9 & 100.0 \\
to satisfy senior management & & & & & \\
Providing misleading information to & 4.9 & 82.5 & 9.9 & 2.7 & 100.0 \\
satisfy the public & & & & & \\
Uses women to attract customers. & 10.2 & 75.0 & 8.9 & 5.9 & 100.0 \\
Adulation & 9.5 & 81.0 & 4.9 & 4.6 & 100.0 \\
Misinformation and manipulation & 8.2 & 82.0 & 7.6 & 2.2 & 100.0 \\
spreads rumors & 1.1 & 90.0 & 5.6 & 3.3 & 100.0 \\
Manipulating public opinion & 3.1 & 85.5 & 9.9 & 1.5 & 100.0 \\
\hline
\end{tabular}

\section{Professional Orientations}

Professionalism in the field of public relations is an ongoing controversial issue in professional and academic circles. Research on this issue focused on indicators such as membership in professional associations, public relations or mass communication degrees, subscriptions to professional journals, heavy media consumption, continuing education, and participation in workshops and training courses.

Table 5.1 shows that when evaluating a public relations job, the majority of respondents place most importance (very important) on the following factors: job security (88.4\%) fringe benefits (84.1), the pay (82.4\%), and the chance to develop a specialty (79\%). These factors were also mentioned as very important: the chance to get ahead in the organization (71.7\%), the chance to help people (70.4\%), autonomy on the job (65.7\%), and the chance to influence public affairs $(63.5 \%)$.

Table 5.1 Factors in Judging a Job (in \%, $N=156$ )

\begin{tabular}{lccccc}
\hline & $\begin{array}{c}\text { Very } \\
\text { important }\end{array}$ & $\begin{array}{c}\text { Fairly } \\
\text { important }\end{array}$ & $\begin{array}{c}\text { Not too } \\
\text { important }\end{array}$ & $\begin{array}{c}\text { Don't } \\
\text { know }\end{array}$ & $\begin{array}{c}\text { Total } \\
\text { \% }\end{array}$ \\
\hline Job security? & 88.4 & 6.9 & 3.9 & 0.9 & 100.0 \\
The chance to help people? & 70.4 & 22.4 & 4.0 & 3.2 & 100.0 \\
The pay? & 82.4 & 15.5 & 1.7 & 0.4 & 100.0 \\
The chance to develop a speciality? & 79.0 & 22.3 & 3.4 & 2.6 & 100.0 \\
The chance to get ahead in the organization? & 71.7 & 24.8 & 6.4 & 1.6 & 100.0 \\
Fringe benefits? & 84.1 & 13.7 & 1.3 & 0.9 & 100.0 \\
The chance to influence public affairs? & 63.5 & 25.3 & 7.2 & 8.0 & 100.0 \\
The amount of autonomy you have. & 65.7 & 27.0 & 5.6 & 1.7 & 100.0 \\
\hline
\end{tabular}

The data in Table 5.2 reveal the great extent of passion and professionalism of women public relations practitioners in Qatar. Findings indicate a high degree of professionalism and dedication. More than two-thirds of the surveyed PR practitioners consider the following factors as very important to their professional orientation the opportunity to learn new skills and knowledge (84\%), improving professional competence (79.2\%).

These factors were also rated as very important: security of the job PR practitioners hold (75.2\%), respect for the ability and competence of co-workers (71.2\%) the prospect of using abilities and training (69.6\%), having a job 
with a respected organization (68.8\%), salary and earning a good living (68.8\%) and getting ahead in your career $(68.8 \%)$.

Table 5.2 Professional Orientations (in $\%, N=156$ )

\begin{tabular}{|c|c|c|c|c|c|c|}
\hline & $\begin{array}{c}\text { Very } \\
\text { important }\end{array}$ & $\begin{array}{c}\text { Fairly } \\
\text { important }\end{array}$ & Important & $\begin{array}{c}\text { Not too } \\
\text { important }\end{array}$ & $\begin{array}{c}\text { No } \\
\text { response }\end{array}$ & $\begin{array}{c}\text { Total } \\
\%\end{array}$ \\
\hline $\begin{array}{l}\text { Opportunity to learn new skills } \\
\text { and knowledge }\end{array}$ & 84.0 & 8.0 & 7.4 & 0.0 & 0.6 & 100.0 \\
\hline $\begin{array}{l}\text { Improving professional } \\
\text { competence }\end{array}$ & 79.2 & 14.4 & 6.0 & 0.0 & 0.4 & 100.0 \\
\hline $\begin{array}{l}\text { Full use of your ability and } \\
\text { training }\end{array}$ & 69.0 & 23.2 & 5.6 & 1.6 & 0.6 & 100.0 \\
\hline $\begin{array}{l}\text { Security of the job the PR } \\
\text { practitioner holds }\end{array}$ & 75.2 & 15.4 & 8.0 & 0.8 & 0.6 & 100.0 \\
\hline $\begin{array}{l}\text { Being with people who are } \\
\text { congenial }\end{array}$ & 61.0 & 28.0 & 9.6 & 0.8 & 0.6 & 100.0 \\
\hline $\begin{array}{l}\text { Having a job that is valuable to } \\
\text { society }\end{array}$ & 72.0 & 18.4 & 8.4 & 0.8 & 0.4 & 100.0 \\
\hline $\begin{array}{l}\text { Opportunity for originality and } \\
\text { initiative }\end{array}$ & 63.2 & 22.4 & 12.2 & 1.6 & 0.6 & 100.0 \\
\hline $\begin{array}{l}\text { Respect for the ability and } \\
\text { competence of co-workers }\end{array}$ & 71.2 & 19.2 & 7.2 & 1.6 & 0.8 & 100.0 \\
\hline $\begin{array}{l}\text { Having a job with a respected } \\
\text { organization }\end{array}$ & 68.2 & 12.8 & 10.4 & 8.0 & 0.6 & 100.0 \\
\hline $\begin{array}{l}\text { Excitement and variety the job } \\
\text { provides }\end{array}$ & 56.4 & 28.4 & 11.2 & 3.2 & 0.8 & 100.0 \\
\hline $\begin{array}{l}\text { Getting ahead in your } \\
\text { organization }\end{array}$ & 68.2 & 21.6 & 8.0 & 2.4 & 0.6 & 100.0 \\
\hline $\begin{array}{l}\text { Supervisors who appreciate } \\
\text { improvement }\end{array}$ & 67.2 & 19.2 & 12.0 & 1.2 & 0.4 & 100.0 \\
\hline $\begin{array}{l}\text { The chance to get ahead in the } \\
\text { organization? }\end{array}$ & 63.2 & 20.8 & 10.4 & 5.2 & 0.4 & 100.0 \\
\hline $\begin{array}{l}\text { Availability of support: } \\
\text { working with people who } \\
\text { support you }\end{array}$ & 55.2 & 31.2 & 20.8 & 20.2 & 0.6 & 100.0 \\
\hline $\begin{array}{l}\text { Enjoyment of what's involved } \\
\text { in doing the job }\end{array}$ & 64.0 & 27.2 & 8.2 & 0.0 & 0.6 & 100.0 \\
\hline $\begin{array}{l}\text { Salary: earning a good } \\
\text { Living }\end{array}$ & 68.0 & 20.2 & 9.6 & 1.6 & 0.6 & 100.0 \\
\hline $\begin{array}{l}\text { Job that connects me with } \\
\text { important people }\end{array}$ & 46.4 & 28.8 & 12.0 & 12.2 & 0.6 & 100.0 \\
\hline $\begin{array}{l}\text { Having an influence on } \\
\text { important decisions }\end{array}$ & 45.0 & 34.4 & 12.0 & 8.0 & 0.6 & 100.0 \\
\hline $\begin{array}{l}\text { Opportunity to have influence } \\
\text { on public }\end{array}$ & 36.0 & 36 & 17.2 & 10.4 & 0.4 & 100.0 \\
\hline $\begin{array}{l}\text { Freedom from close supervision } \\
\text { of your work }\end{array}$ & 36.8 & 37.6 & 20.8 & 4.2 & 0.6 & 100.0 \\
\hline $\begin{array}{l}\text { Having a prestigious job in the } \\
\text { organization }\end{array}$ & 28.4 & 36.0 & 19.2 & 16.0 & 0.4 & 100.0 \\
\hline $\begin{array}{l}\text { Having a job with prestige in } \\
\text { community }\end{array}$ & 27.2 & 31.2 & 20.8 & 20.2 & 0.6 & 100.0 \\
\hline
\end{tabular}

Table 5.3 shows why women PR practitioners in Qatar chose to become a PR professional over four fifths said they strongly agree or somewhat agree with the following: "helping others" (88.4\%), and "love PR" $(87.2 \%)$. Three thirds of the respondents strongly agree or somewhat agree with the following: "dealing with others" $(79.2 \%)$ and a "vocation" (74.7\%). 
Table 53 Reasons for becoming a PR practitioner (in \%, $N=156$ )

\begin{tabular}{lcccccc}
\hline & $\begin{array}{c}\text { Strongly } \\
\text { Agree }\end{array}$ & $\begin{array}{c}\text { Somewhat } \\
\text { Agree }\end{array}$ & $\begin{array}{c}\text { No } \\
\text { Opinion }\end{array}$ & $\begin{array}{c}\text { Somewhat } \\
\text { Disagree }\end{array}$ & $\begin{array}{c}\text { Strongly } \\
\text { Disagree }\end{array}$ & $\begin{array}{c}\text { Total } \\
\mathbf{\%}\end{array}$ \\
\hline Love PR & 65.7 & 21.5 & 7.3 & 3.4 & 2.1 & 100.0 \\
A PR practitioner has a good & 48.9 & 29.6 & 14.2 & 3.9 & 3.4 & 100.0 \\
status in society & & & & & & \\
Want to be famous & 10.7 & 20.6 & 32.2 & 17.6 & 18.9 & 100.0 \\
Want to make money & 18.5 & 30.9 & 19.3 & 16.7 & 14.6 & 100.0 \\
Only job I could get & 15.6 & 15.9 & 15.5 & 13.3 & 39.9 & 100.0 \\
A vocation & 32.2 & 42.5 & 15.0 & 6.4 & 3.9 & 100.0 \\
Helping others & 69.5 & 18.9 & 8.2 & 2.6 & 0.9 & 100.0 \\
Dealing with others & 58.7 & 20.5 & 12.0 & 3.8 & 4.8 & 100.0 \\
\hline
\end{tabular}

\section{Opinion about their publics and their organization's performance}

This study also explored PR practitioners' opinions about their publics (table 6.1). Most

Women PR practitioners agreed with the importance for a PR practitioner to be in touch with publicopinion (86.4\%); PR practitioner generally know what their audience want $(69.6 \%)$. The majority of the interviewees disagreed (78.4\%) with "it is not of great importance to a PR practitioner to know what people think about an issue".

Table 6.1 PR practitioners' Opinion of their publics (in \%, $N=156$ )

\begin{tabular}{|c|c|c|c|c|c|}
\hline & Agree & Disagree & No Opinion & Can't answer & $\begin{array}{c}\text { Total } \\
\%\end{array}$ \\
\hline $\begin{array}{l}\text { PR practitioners generally know what } \\
\text { their audience want. }\end{array}$ & 69.6 & 15.2 & 8.4 & 7.2 & 100.0 \\
\hline $\begin{array}{l}\text { PR practitioners often have } \\
\text { completely wrong ideas about what } \\
\text { the public wants. }\end{array}$ & 27.2 & 56.8 & 10.4 & 5.6 & 100.0 \\
\hline $\begin{array}{l}\text { It is very important for a PR } \\
\text { practitioner to be in touch with public } \\
\text { opinion. }\end{array}$ & 86.4 & 6.4 & 3.2 & 4.0 & 100.0 \\
\hline $\begin{array}{l}\text { It is not of great importance to a PR } \\
\text { practitioner to know what people } \\
\text { think about an issue. }\end{array}$ & 11.2 & 78.4 & 4.0 & 6.4 & 100.0 \\
\hline $\begin{array}{l}\text { There is a great difference between } \\
\text { the opinions of publics and of PR } \\
\text { practitioners. }\end{array}$ & 43.2 & 35.2 & 15.2 & 6.4 & 100.0 \\
\hline $\begin{array}{l}\text { PR practitioners and the public } \\
\text { generally have similar views on most } \\
\text { issues. }\end{array}$ & 48.0 & 34.4 & 11.2 & 6.4 & 100.0 \\
\hline
\end{tabular}

Asked to rate their own PR organization's performance, interviewees rated it as very good (42.9\%), outstanding (36.4\%), and good (15.6\%). (Table6.2).

Table 6.2PR practitioners' opinion about their organization's performance (in \%, $N=156$ )

\begin{tabular}{lc}
\hline Poor & 3.9 \\
Fair & 1.3 \\
Good & 15.6 \\
Very good & 42.9 \\
Outstanding & 36.4 \\
Total & 100.100 .0 \\
\hline
\end{tabular}

\section{Internal and External Communication}

Internal communication positively affects the overall reputation and brand of an organization through empowering individual employees. Table 7.1 shows the kind of channels used by the PR department to achieve a successful internal communication. 
Over four fifths of the respondents said they use internal memos, statements and letters and email and website respectively $(86.4 \%),(80.6 \%)$ and $(80.2 \%)$. Other channels used are meetings $(73.9 \%)$, pamphlets and booklets $(62.9 \%)$ and discussion groups $(55.6 \%)$.

Table 7.1 Channels of Internal communication (in \%, $N=156$ )

\begin{tabular}{lc}
\hline Meetings & 73.9 \\
Seminars & 31.3 \\
Discussion groups & 55.6 \\
Pamphlets and booklets & 62.9 \\
Internal memos & 86.4 \\
Statements and letters & 80.6 \\
Email and website & 80.2
\end{tabular}

External communications is one of the most important measure of professional success in the practice of public relations. Public relations departments strive hard to reach efficiently their stakeholders and various publics. Table 7.2 reveals that the majority of Women public relations practitioners in this survey said they use the following to reach their stakeholders and external publics, news releases (94.6\%), Twitter (92.2\%), annual reports and letters $(84.5 \%)$ and organization website $(75.6 \%)$.

Table 7.2 Channels of External communication (in \%, $N=\mathbf{1 5 6}$ )

\begin{tabular}{ll}
\hline PR campaigns & 43.9 \\
Advertisements in massmedia & 35.3 \\
News releases & 94.6 \\
Booklets and leaflets & 42.9 \\
Conferences & 36.4 \\
Organization's website & 75.6 \\
Annual reports and letters & 84.5 \\
Personal Communication & \\
\hline
\end{tabular}

Concerning their relations within and outside their organization (Table 7.3) four fifths of the respondents in this study said that the relations are excellent or very good within their department (92\%), with the public (87.2\%), and with the media (86.4\%). Over three fourths said that the relations are excellent or very good with other PR departments in other organizations $73.6 \%$ ) and with other departments in your organization (69.6\%).

Table 7.3 PR practitioners' opinion about their relations within and outside their organization

\begin{tabular}{lcccccc}
\hline & Excellent & $\begin{array}{c}\text { Very } \\
\text { good }\end{array}$ & Good & Poor & $\begin{array}{c}\text { No } \\
\text { opinion }\end{array}$ & Total \\
\hline Within your department & 37.6 & 54.4 & 4.8 & 1.6 & 5.6 & 100.0 \\
Within other departments in & 18.4 & 51.2 & 13.6 & 2.4 & 14.4 & 100.0 \\
your organization & & & & & & \\
With other organizations & 27.2 & 55.2 & 8.8 & 3.2 & 5.6 & 100.0 \\
With the public & 26.4 & 60.8 & 5.6 & 1.6 & 5.6 & 100.0 \\
With the media & 24.8 & 61.6 & 4.8 & 0.8 & 8.0 & 100.0 \\
$\begin{array}{l}\text { With PR departments in } \\
\text { other organizations }\end{array}$ & 17.6 & 56.0 & 9.6 & 7.2 & 9.6 & 100.0 \\
\hline
\end{tabular}

\section{Social media use}

Social media is reorganizing the profession of public relations. Since the advent of internet, PR is becoming more and more online and virtual; many of its activities are done through the net. Modern technology transforms the way we send, receive and process information. Social media or online networking sites have been heralded as groundbreaking interactions, which allow networked communication to occur instantaneously. Social media enable PR practitioners to share content, opinions, experiences, insights, views, and media themselves. Social media sites encourage and foster two-symmetrical communication among its participants. Using social media by PR practitioners allow them to reach and interact with multiple publics and stakeholders, thus opening the opportunities and possibilities for mutually beneficial relationships. 
Concerning social media use for public relations activities, table 8.1 shows that electronic mail comes first with $97.2 \%$ followed by Intranet $75.7 \%$ and then respectively by corporate websites and social networks $64.6 \%$, and instant messaging 47. 3\%. Other social used by women PR practitioners in Qatar are: video and photo sharing $30.6 \%$, blogs $30.2 \%$, podcast and wikis $21.7 \%$, and social bookmarking $21.6 \%$.

\begin{tabular}{lc} 
Table 8.1 Tasks to achieve internal communication (in $\mathbf{\%}, \boldsymbol{N}=\mathbf{1 5}$ \\
\hline Social media & $\%$ \\
Electronic mail & 97.2 \\
Intranet & 75.7 \\
Corporate web sites & 64.6 \\
Social networks & 64.6 \\
Instant messaging & 47.3 \\
Video and photo sharing & 30.6 \\
Blogs & 30.2 \\
Podcast & 21.7 \\
Wikis & 21.7 \\
Social bookmarking & 21.6 \\
\hline
\end{tabular}

\section{Research and outsourcing}

On the question of "Have you ever done research and studies in your department", an overwhelming majority said never (92\%). $70 \%$ of the respondents said their department do not utilize third party to carry out research and studies. This is one of the main drawback of the practice of public relations in Qatar as is the case of the majority of the Gulf and Arab countries. (Badran and Ayish 1996, Kirat, 2005, 2006). Public relations practitioners in Qatar focus on technician role of PR and emphasize on publicity and media coverage - Grunig press a gentry and public information models.

\section{Conclusions}

This study draws a portrait of female public relations practitioners in Qatar in terms of educational background, job satisfaction, working conditions, roles, news values, ethics and public opinion. Major findings of the study show that $92 \%$ of female PR practitioners are nationals.

Female PR practitioners in Qatar have a job experience of 8years; over half of them are aged between 35 and 45 years old. Three-quarters of the PR practitioners are married. More than three-quarters of the female PR practitioners in Qatar hold a bachelor's degree or higher, and more than $70 \%$ of them have majored in journalism or mass communication.

More than half of women PR practitioners surveyed indicated a high level of job satisfaction, and three-quarters said that their job conditions are either good or very good. PR practitioners also expressed satisfaction with their freedom in practicing their daily tasks.

About three-quarters of the surveyed PR practitioners responded that they are either satisfied or very satisfied with their jobs, the stability of their jobs, the use of their talents and creativity, and their peer relationships. Overall, these findings suggest that PR practitioners in Qatar are satisfied with their job conditions, which is a positive and healthy sign for the public relations industry in Qatar.

On the other hand, findings from the interviews revealed that PR practitioners are aware of some weaknesses and common criticisms of public relations in Qatar, such as lack of research, counseling and managerial roles. In terms of public relations ethics, the study showed that the PR practitioners learn mostly from peers and colleagues, and from their family and religious upbringing. Seventy eight percent of the surveyed practitioners consistently objected to the use of a range of questionable and unethical practices while performing their job.

PR practitioners in this study also expressed strong support for the idea that the public relations are influential in forming public opinion.

Looking to the future of public relations in Qatar, these findings reveal the need for training and continuing education with specific concentration on modern technology such as databanks, multimedia, and the Internet. 
In addition, there is a need to concentrate on learning different languages, especially English to communicate effectively in a multicultural media environment. Finally, more focus and concentration should be put on research to raise the level of PR professionalism in the country and to engage in more counseling and managerial roles.

Overall, the public relations profession in Qatar needs more focus on quality rather than quantity, this is to say an orientation towards professionalism and excellence. To face these challenges, professionals of PR should focus on the following: Specialized educational preparation to acquire unique knowledge and skills, based on a body of theory developed through research. Recognition by the community of a unique and essential service; autonomy in practice and acceptance of personal responsibility by practitioners and Codes of ethics and standards of performance enforced by a self-governing association of colleagues. (Grunig and Grunig, 2008, Cutlip, Center, and Broom, 2006). Kirat comments on this issue:

The public relations profession has a challenging future in the Arab World. There is an urgent need for the profession to provide services to hundreds and thousands of businesses, institutions, and organizations, whether private or public in all sectors of life. The profession is badly needed to meet the challenges of economic, political and cultural globalization. However; it should be noted that excellent PR departments do not flourish in authoritarian cultures, mechanical structures, asymmetrical communication systems and organizational conditions that devalue freedom of expression and the right to know.(Kirat, 2016).

\section{References}

AlSaqer, Layla (2008) Experience of Female Public Relations Practitioners in Bahrain. Public Relations Review 34, 77-79.

(https://www.csmonitor.com/World/Middle-East/2014/0501/Educated-and-ambitious-Qatari-women-nudgetheir-way-into-the-office).[Accessed: 15 February 2018].

Al Muhannadi, H.S. (2011). The role of Qatari women: Between tribalism and modernity. PhD. Lebanese American University, Beirut, Lebanon.

Al-Subaiey, M. (2015). Qatarization Policy - Implementation Challenges. Brookings Doha Center, [online] Available at: https://www.brookings.edu/wpcontent/uploads/2016/07/06_bdc_essay_winner.pdf [Accessed 5 July 2017].

Badran A. Badran and Muhammad I. Ayish (1996) "Manager and Technician Roles of Public Relations Practitioners in Public and Private Organizations in the United Arab Emirates: An Exploratory Study", paper presented at the conference on "Startegic Planning in Public Relations", Department of Mass Communication, Faculty of Humanities and Social Sciences, United Arab Emirates University, Al-Ain, UAE, December 17-18, 1996.

Bahry, L. and Marr, P. (2005). 'Qatari women: A new generation of leaders?' Middle East Policy, 12(2), pp. 104119.

Embassy of the State of Qatar in Washington, D.C. (2010). Qatari women.[Online]. Available at: http://www.qatarembassy.net/women.asp (Accessed:4 July 2015).

Golkowska, K.U. (2014). Arab women in the Gulf and the narrative of change: The case of Qatar. Interdisciplinary Political and Cultural Journal,16(1), pp. 51-64.

http://www.internetworldstats.com/me/qa.htm. [Accessed: 9 February 2018].

https://data.worldbank.org/indicator/SL.TLF.CACT.FE.ZS

https://www.thepeninsulaqatar.com/article/18/03/2017/Qatar-stresses-commitment-to-women-s-empowerment-inall-fields.

https://portal.moi.gov.qa/wps/portal/MOIInternet/departmentcommittees/publicrelations

Kirat,Mohamed. "PublicRelationsProfessionalism andexcellenceintheArabWorld:

Problemsanddrawbacks",Revue Albahit Alijtima'i,no.12,Spring2016,pp:5-27 .

Kirat, Mohamed. (2012). Journalists in the United Arab Emirates. Weaver, David. H and Lars Willnat. 2012. The Global Journalist in the 21st Century. New York: Routledge, pp: 458-469.

Kirat, Mohamed. (1998). Algerian journalists and their world. In The global journalist: News people around the world, edited by David H. Weaver, pp. 323-348. Cresskill, NJ: Hampton Press, Inc.

Kirat, Mohamed. (1993). The communicators: A portrait of Algerian journalists and their work. Alger: Office des Publications Universitaires. 
Metcalf, B.D. (2007). 'Gender and human resource management in the Middle East'. International Journal of Human Resource Management, 18(1),pp. 54-74.

Mufta, H. (2010). 'How do Qatari females make it to the top? An examination of the organizational constraints to their advancement'. Journal of Women of the Middle East and the Islamic World, 8, pp. 1-23.

Serini, S., Toth, E., Wright, D. \& Emig, A. (1997). Women, men and job satisfaction in public relations. Journal of Public Relations, 24(2), 145-63.

Walker, L. (2014). Female university students in Qatar outnumber men 2:1. [Online]. Available at: http://dohanews.co/female-university-studentsoutnumber- males-nearly/ [Accessed: 14 July 16].

Walker, L. (2016). Qatar home to highest proportion of employed women in the Gulf. [Online]. Available at: http://dohanews.co/qatar-home-to-highestproportion- of-employed-women-in-the-gulf [Accessed: 14 July 16].

Tunstall, Jeremy. (1977). Journalists at work: Specialist correspondents, their news organizations, news sources and competitor colleagues. London: Constable and Co. Ltd. Weaver, David H., and G. Cleveland Wilhoit. 1986. The American journalist: A portrait of U.S. news people and their work. Bloomington, IN: Indiana University Press.

Weaver, David H., and G. Cleveland Wilho it. 1996. The American journalist in the 1990s: U.S. news people at the end of an era. Mahwah, NJ: Lawrence Erlbaum Associates.

Weaver, David H, and Lars Willnat. (2012). The Global Journalist in the 21st Century. New York: Routledge.

Women and the Community, http://www.ashghal.gov.qa/en/AboutQatar/Pages/Women.aspx[Accessed: 9 February 2018]. 